\title{
Perubahan Struktur Vegetasi Pada Sistem Perladangan Gilir Balik Masyarakat Dayak Pitap Kalimantan Selatan
}

\author{
Sri Ulfah ${ }^{\text {a*, Endah Sulistyawati }}{ }^{\mathrm{b}}$ \\ ${ }^{a}$ Program Magister Biologi, Institut Teknologi Bandung, Jl. Ganesha No.10, Lb. Siliwangi, Coblong, Kota Bandung, \\ Jawa Barat-Indonesia \\ ${ }^{b}$ Kelompok Keilmuan Teknologi Kehutanan, Sekolah Ilmu dan Teknologi Hayati, Institut Teknologi Bandung
}

*Email: ulvah.sri@gmail.com

Diterima (received) 15 Maret 2018; disetujui (accepted) 30 Juli 2018; tersedia secara online (available online) 1 Agustus 2018

\begin{abstract}
Shifting cultivation is cultivation system performed alternately from one field to another on forest lands. This study aims to assess changes in structure and composition of vegetation and determine the conditions of environmental factors during shifting period. This research use chronosequence approach at sites with different ages i.e. two, four, six and eight years compared to natural forest using structured form squares $(20 \times 100 \mathrm{~m} 2)$ belt transect comprising several terraced plots. Vegetation parameters were measured for all forms, environmental factors measured were microclimates and edafic factors and soil macro-nutrient content. The results showed that 42 species of 23 families founded in all forms. The vegetation distribution from diameter classes (KD) indicated that KD 0-10 $\mathrm{cm}$ had the highest number of individual density from all research site and declined sharply with the increase of KD. The potential regeneration of tree species vegetation component of each site showed some different patterns. In aspect of microclimates, the temperature decreases along with sites age. Edafic factor did not show any clear pattern with increase of sites age for $\mathrm{C}, \mathrm{N}$ and $\mathrm{P}$, while soil $\mathrm{K}$ levels were significantly higher in the youngest site age than the older sites.
\end{abstract}

Keywords: chronosequence; dayak pitap; shifting cultivation system; succession

\section{Pendahuluan}

Hutan berperan penting sebagai penyedia jasa ekosistem yang mendukung kehidupan manusia. Jasa ekosistem (ecosystem service) merupakan barang atau jasa yang disediakan oleh ekosistem untuk memenuhi kebutuhan manusia (Hein et al., 2006). Untuk beberapa kelompok masyarakat, hutan menyediakan lahan untuk dimanfaatkan dalam sistem perladangan gilir balik. Pertanian gilir balik (perladang berpindah) merupakan sistem penggunaan lahan yang melibatkan 'fase tanam' dan 'fase bera'. Pada fase tanam (masa tanam), hutan dibuka dan dijadikan ladang pertanian dalam satu kurun waktu atau lebih, sedangkan fase bera (masa bera) berlangsung dalam jangka waktu yang lebih lama (Mulyoutami dkk., 2010). Saat masa bera inilah terjadi proses suksesi, dimana tahapan suksesi diawali dengan tumbuhnya tumbuhan perintis yang membutuhkan intensitas cahaya matahari tinggi, untuk pertumbuhannya dan akan tergantikan oleh tanaman berkayu yang berumur lebih panjang hingga mencapai tahap klimaks. Melalui proses suksesi, suatu vegetasi yang telah terkena gangguan akan berkembang dengan membentuk vegetasi baru (Chapin et al., 2002). Pada sistem perladangan gilir balik, suksesi yang terjadi pada masa bera di lahan bekas ladang berperan mengembalikan kesuburan tanah (Iskandar, 1992). hutan yang terbentuk selama masa bera selanjutnya akan dibuka kembali saat petani memerlukan tapak untuk menanam tanaman pertanian kembali.

Pertanian gilir balik ini masih dapat ditemukan di Indonesia. Umumnya perladangan gilir balik dilakukan oleh masyarakat tradisional di kawasan hutan yang terletak di daerah perbukitan. Beberapa kelompok masyarakat tradisional di Indonesia yang menggunakan sistem perladangan gilir balik diantaranya adalah masyarakat Dayak Loksado (Yuliono dkk., 2011), Dayak Juhu (Sovy, 2012), Dayak

doi: https://doi.org/10.24843/blje.2018.v18.i02.p04

(c) 2018 by the authors; Content from this work may be used under the terms of the Creative Commons Attribution 3.0 licence. Any further distribution of this work must maintain attribution to the author(s) and the title of the work, journal citation and DOI. Published under licence by Udayana University, Indonesia. 
Benuaq (Hendra, 2009) dan Dayak Kantu (Sulistyawati, 2001) yang berada di pulau Kalimantan. Masyarakat Baduy (Senoaji, 2012) di pulau Jawa dan masyarakat Talang Mamak (Islamuddin, 2014) di pulau Sumatera.

Banyak persepsi negatif yang berkembang terhadap pertanian gilir balik ini. Sistem pertanian gilir balik dianggap memberikan dampak yang buruk terhadap lingkungan, seperti adanya isu pengurangan cadangan karbon, mengakibatkan erosi serta degradasi tapak. Namun anggapan ini tidak sepenuhnya benar, karena penggunaan sistem pertanian gilir balik ternyata sangat ramah lingkungan sehingga dapat menjaga keanekaragaman spesies, penggunaan sumber daya dan ruang yang efisien, daur ulang nutrisi, pengelolaan dan konservasi air (Knight dalam Altieri, 1990).

Di Kalimantan Selatan, masyarakat Dayak Pitap melakukan sistem pertanian gilir balik dengan cara menggilir ladang dari yang satu ke ladang yang lain yang dibuka dari lahan yang telah ada pada masa bera selama delapan hingga sembilan tahun. Saat diberakan inilah proses suksesi terjadi, dimana terjadi perubahan struktur dan komposisi vegetasi yang sejalan dengan bertambahnya umur vegetasi dan pola perubahannya dipengaruhi oleh beberapa kondisi lingkungan (Corlett, 1995). Tujuan penelitian ini untuk mengkaji perkembangan struktur dan komposisi vegetasi serta kondisi faktor lingkungan selama masa bera pada tapak dua tahun, empat tahun, enam tahun dan delapan tahun. Penelitian ini menggunakan pendekatan chronosequence untuk mempelajari suksesi, yaitu dengan membandingkan vegetasi yang memiliki umur suksesi yang berbeda-beda. Dengan cara ini diharapkan akan tergambarkan pola suksesi yang terjadi pada perladangan gilir balik yang telah diberakan.

\section{Metode}

\subsection{Lokasi Penelitian}

Pelaksanaan penelitian dilakukan pada bulan Juni-September 2015 pada tapak (lahan) gilir balik masyarakat Dayak Pitap di Desa Ajung Kecamatan Tebing Tinggi Kabupaten Balangan, Kalimantan Selatan. Secara umum Desa Ajung, Kecamatan Tebing Tinggi berada pada ketinggian 290 mdpl yang memiliki kemiringan $>40^{\circ}$ dengan curah hujan tahunan $2.319,8 \mathrm{~mm} /$ tahun dan rata-rata bulan basah 10 bulan berikut (BPS Kab. Balangan, 2014). Lokasi penelitian terbagi atas lima tapak pengambilan sampel pada tapak-tapak yang memiliki umur suksesi atau masa bera yang berbeda-beda, yaitu dua tahun, empat tahun, enam tahun dan delapan tahun. Masa bera dihitung sejak ladang ditinggalkan setelah ditanam padi gogo selama satu musim. Keseluruhan tapak penelitian berada di dalam kawasan hutan adat (Gambar 1). Sebagai area pembanding (reference area) yang dianggap mewakili kondisi vegetasi yang tidak terpengaruh oleh perladangan gilir balik, pengamatan juga dilakukan di tapak hutan alami yang merupakan hutan adat masyarakat Dayak Pitap yang berada dalam kawasan Gunung Hauk.

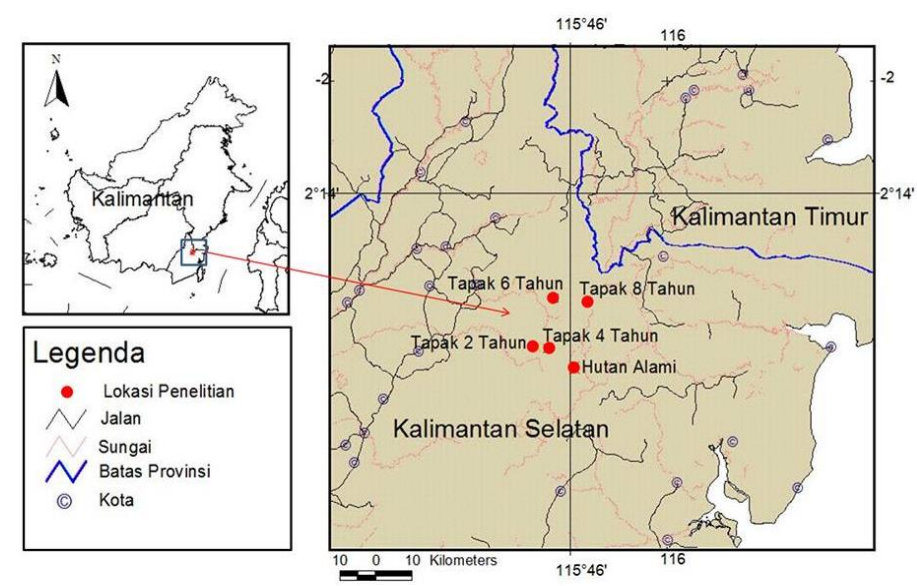

Gambar 1. Peta lokasi penelitian 


\subsection{Pengambilan data}

Pengambilan data penelitian dilakukan dengan metoda belt transect dengan plot besar yang berukuran 20x100 m2 di setiap tapak bera. Secara keseluruhan terdapat empat plot besar pada masingmasing tapak bera berbeda umur dan satu plot besar pada hutan alami. Satu belt transect masing-masing tersusun atas lima buah plot berukuran 20x20 m2 yang diletakkan secara berurutan (Gambar 2). Analisa tahapan hidup pohon (diameter $>20 \mathrm{~cm}$ ) dilakukan pada plot A yang berukuran $20 \times 20 \mathrm{~m} 2$. Dalam plot A terdapat satu sub plot (B) yang berukuran 10x10 m2 untuk analisa tiang (diameter 10-20 cm). Dalam sub plot $\mathrm{B}$ terdapat satu sub plot (C) yang berukuran $5 \times 5 \mathrm{~m} 2$ untuk analisa pancang (diameter $>10 \mathrm{~cm}$ dan tinggi $>30 \mathrm{~cm}$ ) dan perdu (tinggi $>10 \mathrm{~cm}$ ). Dalam sub plot $\mathrm{C}$ terdapat lima sub plot (D) yang berukuran $2 \times 2 \mathrm{~m} 2$ untuk analisa semai (anakan pohon dengan tinggi $<1,5 \mathrm{~m}$ ) dan semai (tumbuhan tidak berkayu) yang tersusun secara sistematis. Pengukuran mikroklimat dan pengambilan sampel tanah dilakukan pada tiga titik.

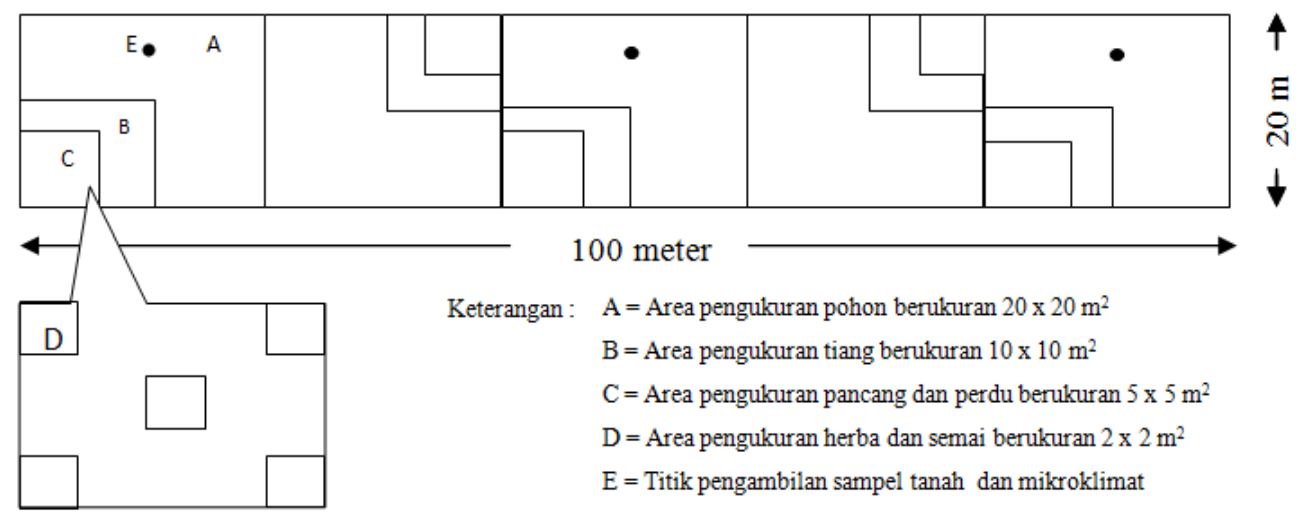

Gambar 2. Bentuk plot pada setiap tapak penelitian

\subsection{Analisis data}

Indeks nilai penting dihitung untuk melihat dominansi spesies dengan menggunakan perhitungan sebagai berikut:

$$
\begin{gathered}
K r R=\frac{\text { kerapatan suatu jenis }}{\text { kerapatan seluruh jenis }} \times 100 \% \\
K b R^{*}=\frac{\text { kerimbunan suatu jenis }}{\text { kerimbunan seluruh jenis }} \times 100 \% \\
F r R=\frac{\text { frequensi } \text { suatu jenis }}{\text { frequensi seluruh jenis }} \times 100 \% \\
L A B^{* *}=\frac{L A B \text { suatu jenis }}{L A B \text { seluruh jenis }} \times 100 \% \\
I N P=K r R+L A B+\text { FrR atau KrR }+K b R+F r R
\end{gathered}
$$

dimana KrR adalah Kerapatan relatif; KbR adalah Kerimbunan relatif; FrR adalah Frequensi relatif; LAB adalah Luas area basal relatif; INP adalah Indeks nilai penting; * adalah pengukuran kerimbunan dilakukan pada perdu dan herba; ** adalah pengukuran LAB dilakukan pada tegakan pohon. 
Tingkat keanekaragaman tumbuhan dapat dianalisis dengan menggunakan Indeks keanekaragaman Shannon-Wiener sebagai berikut;

$$
H^{\prime}=-\sum(P i \ln P i)
$$

dimana H' adalah indeks keanekaragaman; Pi adalah perbandingan jumlah individu satu spesies dengan jumlah individu keseluruhan sampel dalam plot.

\section{Hasil}

Penelitian ini menemukan 42 spesies tumbuhan dari 23 famili disemua bentuk hidup pohon, perdu dan herba. Tabel 1 menujukkan ringkasan penelitian dan tabel 2 menyajikan daftar seluruh spesies yang ditemukan. Pada tahapan bentuk hidup pohon jumlah spesies yang ditemukan akan meningkat seiring dengan bertambahnya umur tapak bera, terkecuali pada hutan alami. Kecenderungan sebaliknya terlihat pada tahapan bentuk hidup perdu dan herba, total spesies menurun sejalan dengan bertambahnya umur bera, terkecuali di hutan alami pada tahapan bentuk herba. Kerapatan pohon di seluruh tapak bera lebih rendah dibandingkan pada hutan alami. Pada tapak hutan alami kerapatan pohon sangat tinggi namun memiliki jumlah spesies yang rendah, ini menggambarkan keragaman spesies yang rendah jika dibandingakan di seluruh tapak bera.

Tabel 1. Ringkasan hasil penelitian pada semua tapak

\begin{tabular}{|c|c|c|c|c|c|c|}
\hline & \multicolumn{5}{|c|}{ Tapak bera } \\
\hline & & 2 Tahun & 4 Tahun & 6 Tahun & 8 Tahun & HA* \\
\hline \multirow{3}{*}{$\begin{array}{c}\text { Total } \\
\text { Spesies }\end{array}$} & Pohon & 2 & 7 & 7 & 10 & 6 \\
\hline & Perdu & 4 & 7 & 7 & 3 & 1 \\
\hline & Herba & 7 & 7 & 4 & 3 & 13 \\
\hline \multirow{3}{*}{$\begin{array}{c}\text { Pohon } \\
\text { DBH } \\
>10 \\
\mathrm{~cm}\end{array}$} & $\begin{array}{ll}\begin{array}{l}\text { Kerapatan } \\
\text { (idv/ha) }\end{array} & \text { Pohon } \\
\end{array}$ & $55 \pm 42,43$ & $111 \pm 87,30$ & $110 \pm 57,65$ & $100 \pm 50,25$ & $158 \pm 59,28$ \\
\hline & Rata-rata diameter $(\mathrm{cm})$ & $14,50 \pm 5,70$ & $19,17 \pm 6,37$ & $23,39 \pm 6,48$ & $23,82 \pm 9,74$ & $23,07 \pm 10,53$ \\
\hline & Basal area $\left(\mathrm{m}^{2} / \mathrm{ha}\right)$ & $74,91 \pm 67,15$ & $654,41 \pm 139,57$ & $632,16 \pm 311,19$ & $1207,67 \pm 242,28$ & $1219,69 \pm 171,4$ \\
\hline
\end{tabular}

*Hutan alami: umur tidak diketahui $\quad$ Kr: Kerimbunan pohon $\quad$ DBH: Diameter at breast height

\subsection{Struktur dan komposisi vegetasi}

Distribusi persebaran kelas diameter seluruh bentuk hidup pohon di seluruh tapak penelitian ditunjukan pada gambar 3. Secara umum, tingkat kerapatan individu pada kelas diameter terkecil (0-10) $\mathrm{cm}$ paling tinggi dibandingkan dengan kelas-kelas diameter yang lain. Pada kelas diameter $0-10 \mathrm{~cm}$ ini, jumlah individu di hutan alami jauh di atas tapak-tapak yang lain. Pada kelas diameter 11-20 cm tingkat kerapatan individu pohon menurun secara tajam dengan kerapatan rata-rata berkisar 400 individu/ha. Pada sebaran kelas diameter 21-30 cm kerapatan individu pohon meningkat dengan kerapatan rata-rata sebanyak 800 individu/ha. Semakin bertambahnya ukuran sebaran kelas diameter kerapatan individu menjadi berkurang hingga mencapai rata- rata kerapatan sebesar 200 individu/ha (kelas diameter 31-40 $\mathrm{cm}$ ) hingga 40 individu/ha (kelas diameter $>40 \mathrm{~cm}$ ).

Dari sebaran ukuran diameter pohon dapat terlihat perkembangan vegetasi sejalan dengan bertambahnya umur bera. Pada tapak-tapak bera yang relatif muda (dua dan empat tahun), komunitas pohon hanya terdiri dari tiga kelas diameter $(0-10 \mathrm{~cm}, 11-20 \mathrm{~cm}$ dan 21-30 $\mathrm{cm})$. Dengan bertambahnya umur bera, ukuran pohon semakin beragam. Pada tapak bera enam tahun, pohon terdistribusi pada empat kelas diameter $(0-10 \mathrm{~cm}, 11-20 \mathrm{~cm}, 21-30 \mathrm{~cm}$ dan 31-40 cm). Pada tapak bera delapan tahun, pohon terdistribusi pada seluruh kelas diameter seperti halnya pada tapak hutan alami.

Kajian struktur dan komposisi vegetasi juga dapat memberikan gambaran tentang potensi regenerasi spesies dalam suatu tapak. Untuk bentuk hidup pohon, regenerasi dapat dilihat dari sebaran individu per tahapan hidup (pohon, tiang, pancang dan semai) yang terdapat pada suatu tapak. Keberadaan suatu spesies di masa datang akan besar peluangnya bila pada tapak tersebut ditemukan cukup banyak individu 
berumur muda atau permudaan. Berdasarkan Gambar 4, pada tapak bera dua tahun terdapat dua spesies yaitu Archidendron paiciflorum dan Hevea brasiliensis. Pada tapak ini, spesies Archidendron paiciflorum memiliki semua tahapan hidup, sedangkan Hevea brasiliensis hanya memiliki tahapan hidup tiang, pancang dan semai. Dilihat berdasarkan sebaran umur spesies yang ada, Archidendron pauciflorum dan Hevea brasiliensis akan mendominasi pada tapak ini.

Tabel 2. Spesies yang ditemukan pada seluruh tapak penelitian

\begin{tabular}{|c|c|c|c|}
\hline $\begin{array}{l}\text { Bentuk } \\
\text { Hidup }\end{array}$ & Spesies & Famili & Nama Umum/Lokal \\
\hline \multirow{14}{*}{ Pohon } & Agathis dammara (Lamb.) L. C. Rich & Araucariaceae & Damar \\
\hline & Aquilaria malaccensis (Lam.) & Thymelaeaceae & Gaharu \\
\hline & Archidendron pauciflorum (Benth.) & Fabaceae & Jengkol/Jaring \\
\hline & Artocarpus integer (Merr.) & Moraceae & Cempedak/Tiwadak \\
\hline & Artocarpus odoratissimus. & Moraceae & Tarap \\
\hline & Durio zibethinus(Murr.) & Bombacaceae & Durian \\
\hline & Hevea brasiliensis (Muell. Arg) & Euphorbiaceae & Karet/Gatah \\
\hline & Macaranga gigantea (Mull. Arg) & Euphorbiaceae & Mahang \\
\hline & Mangifera caesia ( Jack.) & Anacardiaceae & Binjai \\
\hline & Mangifera indica (Jack.) & Anacardiaceae & Mangga \\
\hline & Nephelium lappaceum L. & Sapindaceae & Rambutan \\
\hline & Peronema canescens Jack. & Verbenaceae & Sungkai \\
\hline & Syzygium antisepticum B1.Merry \& Perry & Myrtaceae & Jambu hutan \\
\hline & Vitex pubescen Vahl & Verbenaceae & Laban/Alaban \\
\hline \multirow{7}{*}{ Perdu } & Calamus caesius Blumei & Arecaceae & Rotan sigi \\
\hline & Calamus manan Miquel & Arecaceae & Rotan manau \\
\hline & Calamus paspalanthus Becc. & Arecaceae & Rotan buluk \\
\hline & Calamus trachycoleus Becc. & Arecaceae & Rotan irit \\
\hline & Korthalsia jala J.Dransf. & Arecaceae & Rotan dahanan \\
\hline & Korthalsia robusta Blumei. & Arecaceae & Rotan dahanan \\
\hline & Schizostachyum Nees. & Poaceae & Paring tamiang \\
\hline \multirow{21}{*}{ Herba } & Agrostophyllum majus Blumei. & Orchidaceae & Anggrek \\
\hline & Alpinia galanga var. galanga & Zingiberaceae & Lengkuas/Tipakan \\
\hline & Asplenium nidus $\mathrm{L}$. & Aspleniaceae & Pakis sarang burung \\
\hline & Brachiaria mutica (Forsk.) StapfI & Graminales & Rumput Malela \\
\hline & Bulbophyllum echinolabium J.J.S. & Orchidaceae & Anggrek \\
\hline & Cymbidium sp. & Orchidaceae & Anggrek \\
\hline & Cyperus rotundus $\mathrm{L}$. & Cyperaceae & Rumput teki \\
\hline & Dendrobium aloifolium (B1.) Rchb.f. & Orchidaceae & Anggrek Anyaman \\
\hline & Dendrobium calophyllum & Orchidaceae & Anggrek \\
\hline & Eria hyacinthoides (B1.) Lindl. & Orchidaceae & Anggrek \\
\hline & Hedyotis corymbosa (L.) Lam & Rubiaceae & Rumput mutiara \\
\hline & Mikania micrantha Kunth. & Asteraceae & Sambung rambat \\
\hline & Mimosa pudica L. & Fabaceae & Putri malu \\
\hline & Myrmecodia becari Hook.f. & Rubiaceae & Sarang samut \\
\hline & Nepenthes sp & Nepenthaceae & Kantong semar \\
\hline & Nephrolepis hirsutula (G. Forst.) C. Presl & Dryopteridaceae & Paku kinca \\
\hline & Phyllanthus urinaria $\mathrm{L}$. & Euphorbiaceae & Meniran \\
\hline & Platycerium bifurcatum (Cav.) C. Chr & Polypodiaceae & Tanduk Rusa \\
\hline & Pteris ensiformis Burm. F. & Pteridaceae & Paku pedang \\
\hline & Saccharum spontaneum L. & Poaceae & Gelagah/Tibarau \\
\hline & $\begin{array}{l}\text { Schoenorchis juncifolia (Reinw. Ex } \\
\text { Blume) J.J.Sm. }\end{array}$ & Orchidaceae & Anggrek \\
\hline
\end{tabular}




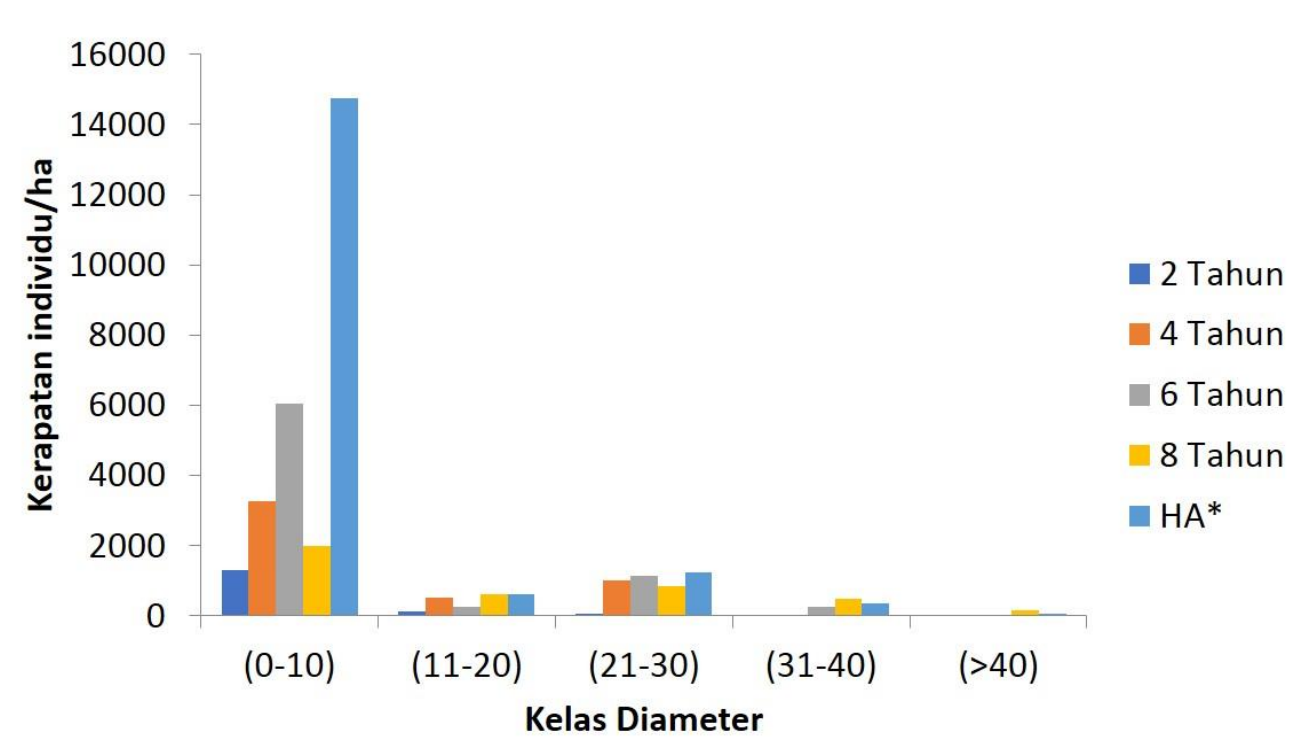

Gambar 3. Kelas diameter di seluruhan tapak penelitian.

Pada tapak bera empat tahun terdapat enam spesies yaitu Archidendron pauciflorum, Hevea brasiliensis, Peronema canescens, Mangifera caesia, Mangifera indica, Nephelium lappaceum dan Vitex pubescen (Gambar 4). Pada tapak ini, spesies Archidendron pauciflorum, Hevea brasiliensis dan Vitex pubesce ada di semua tahapan bentuk hidup sedangkan Peronema canescens memiliki tahapan dewasa dan permudaan (pohon dan semai). Spesies Mangifera caesia memiliki tahapan hidup tiang dan pancang, sedangkan Mangifera indica dan Nephelium lappaceum hanya memiliki tahapan hidup tiang. Dilihat dari sebaran umur spesies yang ada, dapat diprediksi di masa yang akan datang paling tidak terdapat empat spesies yang akan menguasai vegetasi tapak jika dilihat dari ketersediaan permudaannya yaitu spesies Archidendron pauciflorum, Hevea brasiliensis, Peronema canescens dan Vitex pubescen.

Pada tapak bera empat tahun terdapat tujuh spesies yaitu, Agathis dammara, Aquilaria malaccensis, Archidendron pauciflorum, Artocarpus integer, Hevea brasiliensis, Mangifera caesia dan Peronema canescens (Gambar 4). Pada tapak ini spesies Archidendron pauciflorum dan Hevea brasiliensis memiliki tahapan hidup yang lengkap. Agathis dammara memiliki tahapan hidup dewasa (pohon dan tiang) namun tidak memiliki permudaan. Peronema canescens memiliki tahapan hidup pancang dan semai, sedangkan Aquilaria malaccensis, Artocarpus integer dan Mangifera caesia hanya memiliki tahapan hidup semai. Jika dilihat dari sebaran kehadiran spesies pada tapak ini, terdapat tiga spesies yang memiliki potensi regenerasi yang baik yaitu Archidendron pauciflorum, Agathis dammara dan Hevea brasiliensis dimana ketiga spesies tersebut memiliki tahapan bentuk dewasa dan permudaan.

Terdapat spesies sembilan pada tapak bera delapan tahun, yaitu Agathis dammara, Aquilaria malaccensis, Archidendron pauciflorum, Artocarpus odoratissimus, Durio zibethinus, Macaranga gigantea, Mangifera caesia, Peronema canescens dan Vitex pubescen (Gambar 4). Pada tapak ini spesies Peronema canescens dan Agathis dammara merupakan spesies yang memiliki tahapan bentuk hidup yang lengkap. Mangifera caesia hanya memiliki tahap pancang dan Archidendron pauciflorum hanya terdapat pada tahap permudaan namun tidak memiliki bentuk dewasa. Sedangkan Macaranga gigantea terdapat pada tahapan dewasa dan permudaan. Aquilaria malaccensis, Artocarpus odoratissimus dan Durio zibethinus memiliki tahapan dewasa namun tidak memiliki bentuk semai. Pada tapak ini, individu yang tidak memiliki permudaan ada kemungkinan belum memasuki masa reproduksi, sehingga potensi regenerasi spesies tersebut kedepannya pada tapak ini masih belum bisa diprediksi. 


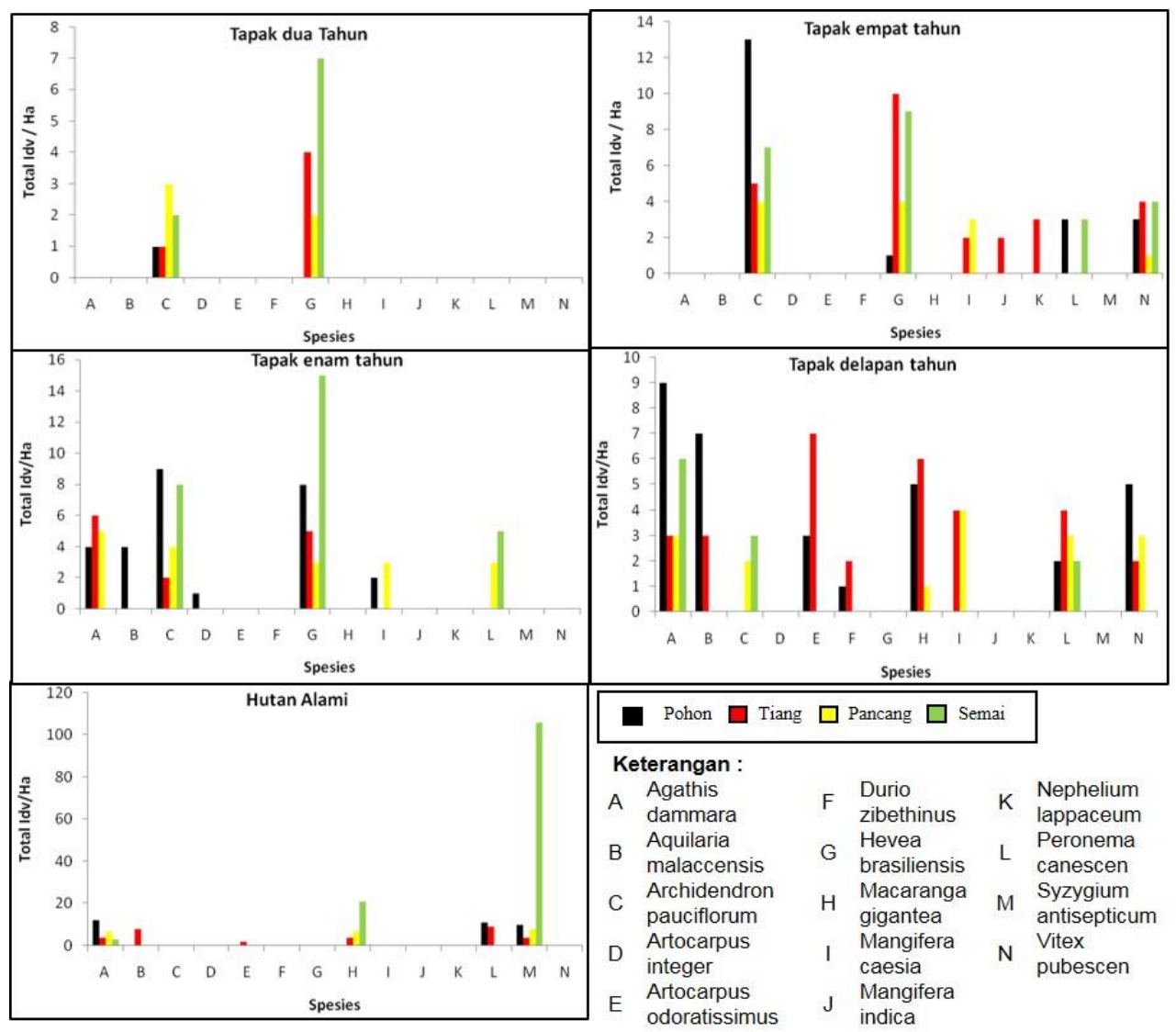

Gambar 4. Regenerasi setiap tahapan bentuk hidup seluruh spesies di tiap tapak penelitian.

Pada hutan alami terdapat enam spesies yaitu Agathis dammara, Aquilaria malaccensis, Artocarpus odoratissimus, Macaranga gigantea, Peronema canescens dan Syzygium antiseptum. merupakan spesies yang memiliki tahap dewasa dan permudaan (Gambar 4). Agathis dammara dan Syzygium antiseptum merupakan spesies yang memiliki tahapan hidup lengkap. Peronema canescens pada tapak ini hanya terdapat pada bentuk hidup dewasa, tidak ditemukan dalam bentuk permudaan. Aquilaria malaccensis dan Artocarpus odoratissimus merupakan spesies yang hanya memiliki tahapan hidup tiang sedangkan Macaranga gigantea tidak memiliki tahapan hidup pohon namun ditemukan pada tahapan lainnya (tiang, pancang dan semai). Berdasarkan data yang didapat, tapak hutan alami dimasa yang akan datang akan didominasi oleh Agathis dammara Macaranga gigantea, Peronema canencens dan Syzygium antiseptum. Namun tidak menutup kemungkinan Peronema canencens akan tetap ada, karena bentuk dewasa Peronema canencens akan memberikan masukan benih pada tapak jika terjadi bukaan kanopi pada hutan.

\subsection{Mikroklimat}

Tabel 3 menunjukkan suhu yang menurun seiring bertambahnya umur bera. Intensitas cahaya tertinggi pada umur bera termuda (6.000 lux) dan semakin menurun dengan bertambahnya umur bera hingga tahun ke delapan (4.800 lux) dan suhu terendah pada tapak hutan alami (790 lux).

\subsection{Faktor Edafik}

Pada awal suksesi $\mathrm{pH}$ tanah tergolong asam namun bertambahnya umur bera $\mathrm{pH}$ tanah meningkat (Tabel 3). Untuk suhu tanah, tapak bera dua memiliki suhu tanah tertinggi karena belum terbentuknya 
naungan oleh tajuk pohon pada tapak ini. Suhu terrendah terdapat pada hutan alami yang dipengaruhi oleh rapatnya tutupan kanopi sehingga menghalangi sinar matahari yang masuk ke lantai hutan. Kelembaban tanah berkisar antara 46\%-60\% dan nilainya cenderung naik dengan bertambahnya umur bera.

Tabel 3. Lingkungan pada masing-masing tapak bera.

\begin{tabular}{ccccccc}
\hline Tapak & \multicolumn{3}{c}{ Mikroklimat } & Edafik \\
\cline { 2 - 6 } & $\begin{array}{c}\text { Intensitas } \\
\text { cahaya }(\text { lux })\end{array}$ & $\begin{array}{c}\text { Suhu udara } \\
\left({ }^{\circ} \mathrm{C}\right)\end{array}$ & $\begin{array}{c}\text { Kelembaban } \\
(\%)\end{array}$ & $\mathrm{pH}$ & $\begin{array}{c}\text { Suhu tanah } \\
\left({ }^{\circ} \mathrm{C}\right)\end{array}$ & $\begin{array}{c}\text { Kelembaban } \\
\text { tanah }(\%)\end{array}$ \\
\hline 2 Tahun & $6.770 \pm 5$ & $32 \pm 0,58$ & $67 \pm 1,53$ & $5,2 \pm 0,06$ & $38 \pm 2,65$ & $46 \pm 0,58$ \\
4 Tahun & $4.027 \pm 70$ & $29 \pm 0,58$ & $55 \pm 1,15$ & $6,2 \pm 0,17$ & $36 \pm 0,71$ & $51 \pm 1,15$ \\
6 Tahun & $4.809 \pm 13$ & $28 \pm 0,58$ & $59 \pm 1,53$ & $6,5 \pm 0,12$ & $32 \pm 1,73$ & $57 \pm 0,58$ \\
8 tahun & $4.749 \pm 213$ & $26 \pm 1,15$ & $60 \pm 1,00$ & $6,5 \pm 0,25$ & $28 \pm 2,08$ & $59 \pm 1,00$ \\
HA* & $794 \pm 20$ & $23 \pm 1,15$ & $50 \pm 1,00$ & $6,7 \pm 0,12$ & $26 \pm 1,00$ & $62 \pm 0,58$ \\
\hline
\end{tabular}

${ }^{*}$ Hutan alami : Umur tidak diketahui

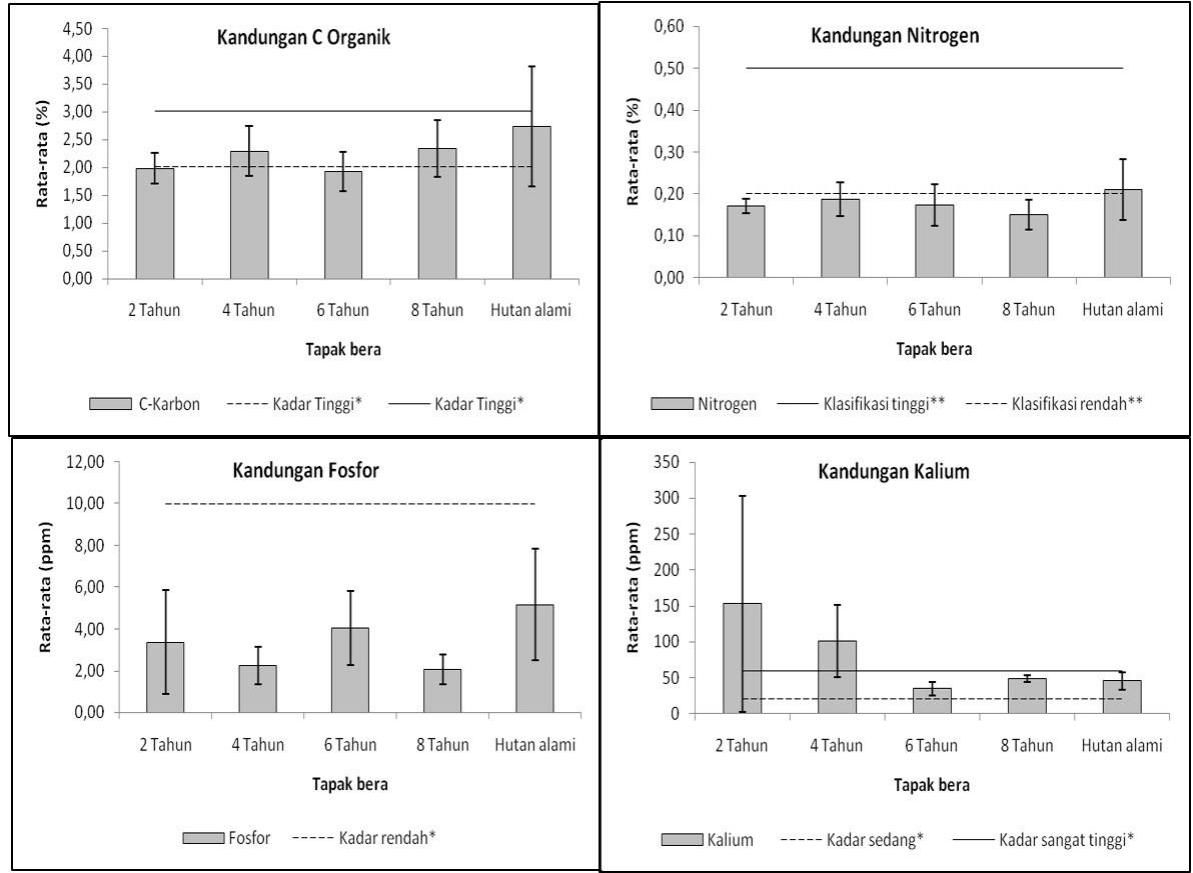

Gambar 5. Kandungan nutrien makro tanah berupa kandungan C organik, N, P dan K di seluruh tapak penelitian (*Pusat Penelitian Tanah (1983 dalam Hardjowigeno, 2003); ${ }^{* *}$ Metson (1961 dalam Landon, 1984).

\subsection{Kandungan Makro Tanah}

Nilai rata-rata kandungan C organik tanah di seluruh tapak berkisar antara 1,92\% - 2,74\% (Gambar 4) dan seluruhnya menurut kriteria Pusat Penelitian Tanah (1983 dalam Hardjowigeno, 2003) kadar ini tergolong "sedang" (Tabel 5). Kandungan C organik diantara tidak menunjukkan pola yang jelas sejalan dengan bertambahnya umur bera namun secara umum tapak-tapak bera nilainya lebih rendah dibandingkan hutan alam. Kadar N (Gambar 5) pada seluruh tapak penelitian cenderung tidak terlalu berbeda (rata-ratanya berada pada kisaran $0,15-0,21 \%$ ) dan tergolong "sedang". Kadar P yang terukur dalam bentuk P2O5 tidak menunjukkan pola yang jelas sejalan dengan bertambahnya umur bera (Gambar 
5) dan semuanya tergolong "sangat rendah" menurut kriteria Pusat Penelitian Tanah (1983 dalam Hardjowigeno, 2003). Berbeda dengan kadar C, N dan P tanah, kadar $\mathrm{K}$ tanah menunjukkan pola yang berbeda. Kadar K tertinggi ditemukan di tapak bera paling muda (dua tahun) dan cenderung menurun sejalan dengan bertambahnya usia bera (Gambar 5). Kadar $\mathrm{K}$ di tanah pada tapak bera dua tahun tergolong "sangat tinggi" sedangkan pada tapak-tapak lain tergolong "sedang" dan "tinggi" menurut kriteria Pusat Penelitian Tanah (1983 dalam Hardjowigeno, 2003). Secara umum dapat dikatakan bahwa untuk faktor edafik berupa kadar unsur-unsur makro, tidak terlihat pola yang jelas sejalan dengan pertambahan umur bera untuk $\mathrm{C}, \mathrm{N}$ dan $\mathrm{P}$ tanah, sedangkan kadar $\mathrm{K}$ tanah jauh lebih tinggi pada tapak bera paling muda dibandingkan dengan tapak-tapak yang lebih tua.

\section{Pembahasan}

Di keseluruhan tapak penelitian (tapak bera semua umur dan hutan alam) ditemukan 42 spesies dari 23 famili yang terdiri dari 14 spesies pohon dari 11 famili, tujuh spesies perdu dari dua famili dan 21 spesies herba dari 13 famili. Diantara spesies yang ditemukan, beberapa hadir di hampir seluruh tapak bera, yaitu Archidendron pauciflorum dan Hevea brasiliensis (pohon); Calamus paspalanthus, Korthalsia jala, Korthalsia robusta dan Schizostachyum blumei (perdu); dan Cyperus rotundus, Hedyotis corymbosa, Nephrolepis hirsutula dan Phyllanthus urinaria (herba).

\subsection{Stuktur dan komposisi vegetasi}

Secara umum hasil penelitian menunjukkan bahwa peningkatan umur bera diikuti dengan meningkatnya jumlah individu ukuran besar. Adanya pembukaan lahan perladangan menjadikan pohonpohon yang memiliki ukuran diameter besar menjadi berkurang dan memberikan pengaruh terhadap regenerasi pohon selanjutnya. Tingginya tingkat kerapatan individu pada kelas diameter kecil $(0-10 \mathrm{~cm})$ dibandingkan dengan kelas diameter lainnya menunjukkan bahwa kerapatan pohon per satuan luas pada tingkat semai, pancang, tiang dan pohon semakin sedikit sehingga permudaan mampu mengisi vegetasi tahapan tingkat lanjut. Pada sebaran kelas diameter, tapak tua (tapak bera enam tahun, delapan tahun dan hutan alami) yang mana telah banyak memiliki individu pohon dengan umur dewasa sehingga dapat menghasilkan permudaan dengan ukuran diameter pohon yang berbeda-beda. Hal ini lah yang menjadikan tapak tua memiliki sebaran diseluruh kelas diameter. Secara umum jumlah individu terbanyak pada kelas diameter kecil, tergolong sedikit dan semakin berkurang dengan bertambahnya ukuran kelas diameter. Pola yang didapatkan pada seluruh kelas diameter menunjukkan "J" terbalik seperti yang dikatakan oleh Whitmore (1990) dalam Sidiyasa (2009) dimana secara umum hutan hujan tropis yang menggambarkan satu komunitas hutan yang dinamis.

Potensi regenerasi bentuk hidup pohon pada setiap tapak menunjukkan regenerasi yang berbeda. Ditemukannya bentuk dewasa pada beberapa spesies memberikan alasan kehadiran permudaan pada spesies tersebut dan tegakan yang ditemukan telah mencapai masa reproduksi sehingga memberikan masukan benih disekitar tapak. Namun terdapat faktor luar yang menjadikan alasan kehadiran permudaan pada suatu tapak, seperti lokasi tapak yang berdekatan dengan hutan tanam. Seperti yang ditemui pada Hevea brasiliensis yang menunjukkan regenerasi secara alami yang berasal dari dispersal benih yang bersumber dari lokasi lain. Faktor lainnya adalah adanya sejarah penanaman pada spesies tertentu dan faktor mikroklimat, seperti pada spesies Peronema canescens yang diduga pernah dilakukan penanaman pada spesies ini dan merupakan spesies pioner (Rasnovi, 2006). Dimana spesies pioneer merupakan spesies yang dapat tumbuh dengan cepat pada lahan terbuka (Slik, 2006). Hal ini didukung dengan tapak hutan alami yang memiliki tutupan kanopi yang rapat sehingga intensitas cahaya yang masuk sangat sedikit (Tabel 3) sehingga pada tapak tersebut tidak ditemukan Peronema canescens dalam bentuk permudaan. Kehadiran beberapa spesies dapat pula dipengaruhi oleh kelompok jenis spesies itu sendiri. Seperti spesies Macaranga gigantea yang baru ditemukan pada tapak berumur tua (tapak bera delapan tahun), sedangkan dalam penelitian lain menunjukkan bahwa spesies ini merupakan spesies indikator jika telah terjadi gangguan besar pada suatu habitat (Slik dkk, 2003) sehingga banyak ditemukan pada 
penelitian yang mengkaji suksesi pada vegetasi yang telah terganggu (Riswan dan Abdulhadi, 1992; Lawrence dkk., 2005).

Secara keseluruhan potensi regenerasi spesies pohon penyusun vegetasi setiap tapak menunjukkan pola yang berbeda-beda. Ditemukannya bentuk dewasa pada beberapa spesies memberikan masukan benih di sekitar tapak. Ditemukan juga bentuk permudaan namun tidak memiliki bentuk tegakan dewasa. Hal ini diduga kuat karena ada faktor luar mempengaruhi ketersediaan permudaan tersebut, diantaranya lokasi tapak yang berdampingan dengan hutan tanaman dan adanya sejarah penanaman dari spesies tertentu.

\subsection{Faktor Lingkungan}

Penurunan suhu udara terkait dengan intensitas cahaya yang dipengaruhi oleh masukan sinar matahari yang sampai di lantai hutan. Terlihat bahwa rendahnya intensitas cahaya di hutan alami terkait dengan rapatnya tutupan tajuk sehingga menyebabkan rendahnya suhu udara pada tapak tersebut. Pada kelembaban udara tidak terlihat pola yang jelas, ini sesuai dengan pola umum perubahan kondisi lingkungan dalam suksesi. Chapin et al. (2002), menyatakan bahwa pada awal suksesi suhu udara akan sangat tinggi namun akan menurun pada tahun berikutnya. Tinggi suhu udara pada tapak bera dua tahun terjadi karena belum terbentuknya naungan oleh tajuk pohon dan rendahnya suhu udara pada hutan alami dipengaruhi oleh rapatnya tutupan kanopi sehingga menghalangi sinar matahari yang masuk ke lantai hutan. Secara keseluruhan kondisi $\mathrm{pH}$ tanah pada tapak menunjukkan kondisi yang sesuai dengan tanah pertanian pada umumnya (6.3-7.5), terkecuali kondisi $\mathrm{pH}$ pada tapak bera dua tahun yang berada dibawah batas toleransi.

\subsection{Kandungn Makro Tanah}

Nilai rata-rata kandungan C di seuruh tapak berkisar antara 1,92\% - 2,74\% (Gambar 5), yang mana menurut kriteria Pusat Penelitian Tanah (1983 dalam Hardjowigeno, 2003) kadar ini tergolong kadar yang sedang. Hal ini menunjukkan bahwa masih belum tinggi serasah yang belum terdekomposisi di seluruh tapak, dimana jatuhan serasah yang sedikit atau proses dekomposisi yang berlangsung lama namun tidak menyisakan residu tumbuhan. Diduga hal inilah yang terjadi pada tapak bera dua tahun dan enam tahun yang memiliki kadar $\mathrm{C}$ paling rendah sehingga menunjukkan pola yang tidak jelas. Pola yang berbeda ditunjukkan oleh Morisada dkk. (2000) dimana kadar C akan menurun seiring bertambahnya umur tapak. Menurut kriteria Metson (1961 dalam Landon, 1984) kadar N diseluruh tapak termasuk katagori rendah dengan pola yang tidak jauh berbeda (stabil), namun pola yang berbeda ditunjukkan oleh Morisada dkk. (2000) yang mana menurut Scott (1978) dalam Morisada dkk. (2000) seiring berjalannya proses suksesi maka penyimpanan kadar $\mathrm{N}$ di dalam tanah akan semakin menurun. Rendahnya kadar $\mathrm{N}$ pada tanah menurut Morisada dkk. (2000) dan Fawnia (2004) dipengaruhi oleh pH, tingkat biomassa, dekomposisi dan tekstur tanah. Pendapat ini tidak sesuai dengan data yang didapat di tapak penelitian, dimana kadar pH mendekati netral. Diduga ada faktor lain yang mempengaruhi rendahnya kadar $\mathrm{N}$ pada seluruh tapak penelitian. Kadar P tertinggi ditunjukkan pada hutan alami dan kadar terendah pada tapak bera delapan tahun. Pola ini sama seperti yang ditunjukkan oleh Sovy (2012). Tingginya kadar P pada hutan alami sejalan dengan tingginya tingakat keasaman tanah $(>6,5)$ dan tutupan tajuk yang rapat, ini juga diperkuat dengan data intensitas cahaya yag rendah pada hutan alami. Hal ini sesuai dengan pendapat Krebs (2009), Morisada dkk. (2000) dan Sovy (2012) dimana ketersediaan P di dalam tanah dipengaruhi oleh pH sekitar 6,5, intensitas penggunaan tapak, erositas tanah, morfologis dan tutupan vegetasi. Kadar $\mathrm{K}$ tertinggi terdapat pada tapak dua tahun dan kadar terendah terdapat pada tapak bera enam tahun. Menurut Diekmann et al. (2007) pada sistem gilir balik terjadinya pola penurunan dan peningkatan kadar K dalam tanah berhubungan dengan perubahan penutupan vegetasi. Hal ini diduga yang menjadi faktor rendahnya kadar K pada tapak bera dua tahun.

Secara keseluruhan, pada aspek mikroklimat, suhu udara menurun sejalan dengan bertambahnya umur bera. Pola ini terkait dengan besarnya intensitas cahaya yang menunjukkan kecederungan serupa. Secara umum dapat dikatakan bahwa untuk faktor edafik tidak terlihat pola yang jelas sejalan dengan 
pertambahan umur bera untuk $\mathrm{C}, \mathrm{N}$ dan $\mathrm{P}$ tanah, sedangkan kadar $\mathrm{K}$ tanah jauh lebih tinggi pada tapak bera paling muda dibandingkan dengan tapak-tapak yang lebih tua.

\section{Kesimpulan}

Secara keseluruhan disimpulkan bahwa kegiatan perladangan gilir balik menimbulkan dampak terhadap keanekaragaman spesies, struktur tegakan, potensi regenerasi yang memberikan pengaruh terhadap faktor lingkungan dan kandungan makro nutrient tanah.

\section{Ucapan terimakasih}

Penulis menyampaikan terima kasih yang setinggi-tingginya kepada Dirjen Pendidikan (DIKTI) dan Politeknik Negeri Tanah Laut atas beasiswa dan kesempatan belajar yang diberikan. Terima kasih kepada sleuruh masyarakat Dayak Pitap Kabupaten Balangan Kalimantan Selatan dan semua pihak yang telah membantu dalam akses lokasi penelitian dan pengambilan data di lapangan.

\section{Daftar Pustaka}

Altieri, M. A. (1990). Why study traditional agriculture?. Berkeley, USA: McGraw-Hill Inc..

Chapin III, F. S., Matson, P. A., \& Mooney H. A. (2002). Principles of terrestrial ecosystem ecology. New York, USA: Springer-Verlag.

Diekmann, L. O., Lawrence D., \& Okin, G. S. (2007). Changes in the spatial variation of soil properties following shifthing cultivation in a Mexican tropical dry forest. Biogeochemistry, 84(1), 99-113.

Fawnia, S., Sulistyawati, E., \& Adianto. (2004). Keadaan ekologi hutan dan tapak bekas ladang berpindah (reuma) di Kawasan adat Baduy. Dalam Seminar MIPA IV di Institut Teknologi Bandung. Bandung, Indonesia, 6-7 Oktober 2004.

Hardjowigeno, S. (2003). Ilmu Tanah Ultisol. Edisi Baru. Jakarta, Indonesia: Akademika Pressindo,

Hein, L., Van Koppen, K., De Groot, R. S., \& Van Ierland, E. C. (2006). Spatial scales, stakeholders and the valuation of ecosystem services. Ecological economics, 57(2), 209-228.

Hendra, M. (2009). Etnoekologi perladangan dan kearifan botani lokal masyarakat Dayak Benuaq di Kabupaten Kutai Barat Kalimantan Timur. Disertasi. Bogor, Indonesia: Sekolah pascasarjana, Institut Pertanian Bogor.

Iskandar, J. (1992). Ekologi perladangan di Indonesia: studi kasus dari daerah Baduy, Banten Selatan, Jawa Barat. Jakarta, Indonesia: Djambatan.

Islamuddin, I. (2014). Pengembangan Budaya Suku Talang Mamak Sebagai Nilai-Nilai Kearifan Lokal Dalam Bagian Civic culture (Studi Etnografi pada masyarakat suku Talang Mamak di Kecamatan Rakit Kulim, Kabupaten Indragiri Hulu, Propinsi Riau). Jurnal Pendidikan Ilmu Sosial, 23(2), 5567.

Krebs, C. J. (2009) Ecology: The Experimental Analysis of Distribution and Abundance. San Francisco, USA: Pearson Benjamin Cummings,.

Lawrence, D., Suma, V., \& Mogea, J. P. (2005). Change in species composition with repeated shifting cultivation: limited role of soil nutrients. Ecological applications, 15(6), 1952-1967.

Landon, J. R. (1984). Booker tropical soil manual : a handbook for soil survey and agricultural land evaluation in the tropics and subtropics. New York, USA: Longman.

Morisada, K., Effendi, S., \& Ohta, S. (2000). Changes in soil nutrient status after abandonment of swidden agriculture at Benuaq Dayak Village. In Rainforest Ecosystems of East Kalimantan. Tokyo, Japan, (pp. 69-77). 
Mulyoutami, E., Van Noordwijk, M., Sakuntaladewi, N., \& Agus, F. (2010). Perubahan Pola Perladangan: Pergeseran persepsi mengenai para peladang di Indonesia. Bogor, Indonesia: World Agroforestry Centre.

Rasnovi, S. (2006). Ekologi regenerasi tumbuhan berkayu pada sistem agroforest karet. Disertasi. Bogor, Indonesia: Sekolah Pasca Sarjana, Institut Pertanian Bogor.

Senoaji, G. (2012). Pengelolaan lahan dengan sistem agroforestry oleh masyarakat Baduy di Banten Selatan. Bumi Lestari Journal of Environment, 12(2), 283-293.

Sidiyasa, K. (2009). Struktur dan komposisi tegakan serta keanekaragamannya di hutan lindung Sungai Wain, Balikpapan, Kalimantan Timur. Jurnal penelitian hutan dan konservasi alam, 6(1), 79-93.

Slik, J.W.F. 2006. Trees of Sungai Wain. Diperoleh melalui situs internet: http://www.nationalherbarium.nl/sungaiwain. Diunduh pada tanggal 17 April 2016.

Slik, J. W. F. (2006). Trees of Sungai Wain. [online] National Herbarium Nedherland, Leiden University Branch, Leiden, Netherlands, (http://www.nationalherbarium.nl/sungaiwain), [diakses: 15 Februari 2019]

Slik, J. W. F., Keßler, P. J., \& Van Welzen, P. C. (2003). Macaranga and Mallotus species (Euphorbiaceae) as indicators for disturbance in the mixed lowland dipterocarp forest of East Kalimantan (Indonesia). Ecological Indicators, 2(4), 311-324.

Riswan, S., \& Abdulhadi, R. (1992). Succession after disturbance of lowland mixed dipterocarp forest by shifting agriculture in East Kalimantan, Indonesia. In Tropical forests in transition. Basel, Switzerland. (pp. 77-84).

Sovy, M. V. (2012). Kajian adat bahuma dalam mendukung keberlanjutan ladang berpindah (Studi Kasus Desa Juhu, Hulu Sungai Tengah, Kalimantan Selatan). Tesis. Yogyakarta, Indonesia: Sekolah Pascasarjana, Universitas Gadjah Mada.

Sulistyawati, E. .2011. An agen-based simulation of land-use in a swidden agricultural landscape of the Kantu' in Kalimantan, Indonesia. Thesis. Canberra, Australia: Institute of Advanced Studies, The Australian National University.

Yuliono, A., Hamdani, Kurniawan, Y. (2011). Sistem usaha tani perladangan gilir balik masyarakat Dayak Meratus di Desa Haratai Kecamatan Loksado Kabupaten Hulu Sungai Selatan Kalimantan Selatan. Jurnal agribisnis perdesaan, 1(3), 191-205.

Zuhri, M., \& Mutaqien, Z. (2011). Perubahan komposisi vegetasi dan Struktur pohon pada plot Meijer (1959-2009) di Gunung Gede, Jawa Barat. Buletin Kebun Raya, 14(1), 37-45. 